\title{
INTELIGENCKIE BIOGRAFIE NA BIAtORUSI. STUDIUM PRZYPADKU
}

SYTUACJA POGRANICZA

S łabo zarysowana tożsamość białoruska to nieodłączny atrybut sytuacji pogranicza (geopolitycznego, etnicznego, kulturowego, wyznaniowego i językowego). Tereny wchodzące obecnie w skład państwa białoruskiego tradycyjnie „były pograniczem dwóch cywilizacji: bizantyjskiej i zachodnioeuropejskiej" (Kraucewicz 1999: 18). Jest to obszar wielowyznaniowy, z przemieszaniem wpływów kultury bizantyjskiej i romańskiej, co odróżnia Białoruś od innych państw poradzieckich. Jak pokazują chociażby wyniki badań Antoniny Kłoskowskiej (1996), Białorusini wykazują słabą walencję kulturową. W przeciwieństwie do polskiej kultury romantycznej (do której zwykle się odwołujemy jako do podstawowego wzorca polskiego kanonu narodowego), ani podręczniki białoruskie, ani białoruska kultura ludowa, ani literatura piękna nie oferowały szerokim kręgom czytelniczym wartości patriotycznych. Przeważnie występujący w rodzimym kanonie literackim obraz Białorusina to wizerunek uciemiężonego chłopa, a Białorusi jako kraju na rozdrożach, uciskanego przez silniejszych sąsiadów.

Dziewiętnastowieczni przywódcy ruchu odrodzeniowego wyłonili się głównie ze szlachty katolickiej. Również dziewiętnastowieczna literatura białoruska rozwijała się w oparciu o polską myśl polityczną, czerpała z polskiego etosu niepodległościowego i antagonizmów wobec Rosji:
Mgr Natalia MAMUL jest asystentem W Państwowej Wyższej Szkole Zawodowej w Skierniewicach, doktorantką w Katedrze Socjologii Kultury Uniwersytetu Łódzkiego. natalia.mamul@gmail.com 
Początki świadomości narodowej białoruskiej uznawano powszechnie nie tylko jako zjawisko późne historycznie, datowane na drugą połowę XIX wieku, lecz także jako wynik wpływów zewnętrznych. Niektórzy autorzy uważali, że był to przede wszystkim wynik działalności polskich ziemian oraz pisarzy, pragnących dowieść „tubylcom” ich odrębność od Rosjan i związać z polskimi tradycjami. Zaczątki literatury białoruskiej dostrzegano wyłącznie w kręgu przyjaciół Adama Mickiewicza (Tomaszewski 1991: 230).

Tendencje przeciwną, również odmawiającą Białorusinom autonomii w zakresie budowania tożsamości narodowej, można odnaleźć w poglądach propagatorów zapadnorusizmu (zachodniorusizmu):

Zapadnorusizm to nurt w społeczno-politycznej i historiograficznej myśli rosyjskiej odmawiający samodzielności istnienia białoruskiego etnosu, w którym Białorusini rozpatrywani są jako zachodni Rosjanie - zapadnorusy. Początkowo zapadnorusizm miał charakter antypolski, później jednak na głównego jego przeciwnika wyrasta białoruski nurt narodowy (Buczyński 2010: 12).

\section{WIELOJĘZYCZNOŚĆ}

Umacnianiu się białoruskiej tożsamości narodowej nie sprzyja również wielojęzyczność. W różnych okresach historycznych status języka oświaty i liturgii, czyli języka wysokiego przysługiwał językowi rosyjskiemu bądź polskiemu, podczas gdy język białoruski utożsamiany był z prostą mową chłopstwa. Sytuację tę można określić mianem społecznie uwarunkowanej dyglosji (por. Engelking 2001):

Tak więc w społecznościach wielojęzycznych wybór któregoś z języków w danej sytuacji nie jest przypadkowy. To społeczeństwo ustala strefy użycia poszczególnych języków i nadaje im określoną wartość - status języka niskiego bądź wysokiego, intymnego lub oficjalnego itp. Z każdym językiem wiąże się również z góry określona postawa, wynikająca z przypisanej mu funkcji i stanowiąca o jego niskiej lub wysokiej pozycji. Zwykle prestiżem cieszą się języki literackie, mające formę standardową, używane w sytuacjach oficjalnych i dające większe możliwości awansu społecznego (Straczuk 1999: 19).

Warto pokusić się o stwierdzenie, że mieszkańcy Białorusi są z reguły osobami dwujęzycznymi (znają język rosyjski i białoruski): według spisu ludności z 1999 roku 82\% mieszkańców Białorusi deklarowało język białoruski jako swój język ojczysty (por. 1989 - 78\%), a około 38\% stwierdziło, że rozmawia w domu po białorusku. Nawet pobieżny obserwator zauważy natomiast, że mieszkańcy miast białoruskich mówią prawie wyłącznie po rosyjsku, mieszkańcy wsi natomiast głównie używają gwar białoruskich (mówią tzw. „trasianką"). Poza tym, rosyjski jest językiem kultury popularnej i środków masowego przekazu.

Przedstawiciele elit demokratycznych posługują się literackim językiem białoruskim, co nadaje literackiemu białoruskiemu wartość symboliczną:

Dopiero gdy język urasta do symbolu jakiejś grupy, zaczyna odgrywać rolę determinującą. Nie jest już wówczas jedynie elementem codziennego doświadczenia, ale staje się zewnętrznym znakiem, będącym wyrazem odczuwanych więzi ideologicznych. Aby do tego doszło, konieczne jest zaistnienie takiego języka w sferze wysokiej - bo tylko język czysty ma odpowiedni prestiż (Straczuk 1999: 68).

Kiedy za rządów Aleksandra Łukaszenki język białoruski znowu popadł w niełaskę, po raz kolejny stał się silnym symbolem odrodzenia narodowego i narzędziem walki $\mathrm{W}$ rę- 
kach opozycji. Obecnie mówienie po białorusku (z tym zastrzeżeniem, że „czystym” biatoruskim, a nie wiejskim dialektem) jest wyrazem sprzeciwu wobec istniejącego reżimu, a sam język białoruski jest postrzegany jako język przyszłych elit rządzących:

Mówienie po białorusku to akcja polityczna; mówić po białorusku znaczy przeciwstawiać się autorytarnemu reżymowi Łukaszenki. Powiązanie między tożsamością językową a polityką stanowi bazę ideologiczną dla Frontu Narodowego i organizacji zrzeszających intelektualistów (Goujon 1999: 670).

Dzieła najwybitniejszych pisarzy i poetów nie pojawiają się na księgarskim rynku ilekroć nie odpowiadają obecnej ideologii administracji rządowej. Ponieważ twórczość w języku białoruskim w ostatniej dekadzie nabrała symbolicznych cech opozycyjności, prawie wszystko, co w tym języku powstaje i jest wartościowe, funkcjonuje w obiegu nieoficjalnym. Oznacza to powrót do czasów wspótistnienia kultury oficjalnej i kultury drugiego obiegu. Jeśli chodzi o strategię językową, kulturową, polityczną i społeczno-gospodarczą, za czasów Łukaszenki doszło do powrotu do polityki radzieckiej (Goujon 1999: 1).

Łukaszenka kontynuuje radziecką politykę dwujęzyczności, kiedy białoruskość była postrzegana jako wtórna wobec radzieckości. W Związku Radzieckim funkcjonowało pojęcie „drugiego języka ojczystego" przy założeniu, że „pierwszym językiem ojczystym” dla wszystkich obywateli radzieckich był język rosyjski. Promowany był także wizerunek języka rosyjskiego jako języka kultury wysokiej (początkowo w swoich przemówieniach Łukaszenka również podkreślał wyższość kultury i języka rosyjskiego, por. Goujon 1999), a języków narodowych jako języków życia codziennego. Warto odnotować, że takie podejście do języków narodowych cechowało większość państw imperialnych, jak na przykład Wielką Brytanię (por. Anderson 1997; Eames 1997).

HISTORIA PAŃSTWOWOŚCI I PAMIĘĆ HISTORYCZNA

Niepewna historia białoruskiej państwowości stanowi kolejną przeszkodę na drodze konsolidacji białoruskiej tożsamości narodowej. Przed uzyskaniem niepodległości w 1991 roku, jedynym krótkim okresem suwerenności Białoruś cieszyła się w latach 1918-1919. Dnia 25 marca 1918 roku w warunkach okupacji niemieckiej proklamowano Białoruską Republikę Ludową. Mimo że Białoruska Republika Ludowa nie była uznana na arenie międzynarodowej za byt niepodległy i została 1 stycznia 1919 roku zastąpiona Białoruską Socjalistyczną Republiką Radziecką, fakt ten stanowi ważny odnośnik w historiografii etnocentrycznej. Późniejsze przesunięcie granic miało miejsce w 1939 roku, kiedy na mocy Paktu Ribbentrop-Mołotow Związek Radziecki anektował wschodnie ziemie Polski. W 1945 roku granice między Polską a Białoruską Republiką Radziecką wytyczono na linii Curzona (dawna granica Królestwa Polskiego). Ostatecznie, Białoruska Republika Radziecka przestała istnieć w 1991 roku. Białoruś formalnie ogłosiła niepodległość 27 lipca 1990 roku na mocy Deklaracji o suwerenności państwowej BSSR. Dnia 25 sierpnia 1991 roku państwu nadano nazwę Republiki Białoruś. W praktyce pełną niezależność Białoruś i inne republiki radzieckie uzyskały na mocy układu białowieskiego z dnia 8 grudnia 1991, który ogłosit rozwiązanie ZSRR i powołanie Wspólnoty Niepodległych Państw. Stanisław Szuszkiewicz stanął na czele rządu i stworzył klimat dla zmian demokratycznych i liberalizacji gospodarczej. Proces ten został zatrzymany po dojściu do władzy obecnego prezydenta kraju, Aleksandra Łukaszenki, w 1994 roku. 
Wśród szeregu czynników stanowiących o słabości procesu narodotwórczego na Białorusi Ryszard Radzik (2002) wyróżnia słabość świadomości historycznej (pamięci przeszłości). Na Białorusi nie ma płaszczyzny dla swobodnej wymiany pamięci biograficznej czy pracy nad pamięcią zbiorową. Mówiąc o ramach pamięci zbiorowej we współczesnej Białorusi, należy wspomnieć, że z jednej strony są one kształtowane przez dominujący dyskurs historyczny zakorzeniony w zinstytucjonalizowanej radzieckiej historiografii, z drugiej zaś przez historię „dysydencką”, która stanowi przeciwwagę wobec historii urzędowej. Dodatkowo istnieje pamięć jednostkowa, reprezentująca biograficzny wymiar wspomnień. Nie sposób przezwyciężyć podziału i nierzadko sprzeczności pomiędzy doświadczeniami jednostkowymi a urzędową pamięcią historyczną z powodu braku mechanizmów swobodnego przepływu między różnymi wymiarami pamięci.

Wojciech Józef Burszta, omawiając typologię europejskich stref nacjonalistycznych na podstawie pracy Ernesta Gellnera Encounters with Nationalism (1994), zgodnie z którą Europa Środkowo-Wschodnia leży w strefie III, konstatuje:

W omawianej strefie współegzystują ze sobą narody "historyczne", które miały byt państwowy, lecz go utraciły, oraz narody „bez historii”, wymagające zdefiniowania politycznego raczej w kategoriach kultury a nie historii (Burszta 2004: 157-8).

Nie możemy zatem przecenić roli inteligencji w tworzeniu i szerzeniu kultury białoruskiej:

W nowszej literaturze przedmiotu panuje w zasadzie zgodność co do tezy, która jeszcze nie tak dawno temu uchodziłaby za paradoks: że mianowicie nowoczesne narody zostały wykreowane przez intelektualistów. Należy to tak rozumieć, że u początków procesu budowania zbiorowej tożsamości narodu są zawsze dzieła jego wykształconych ideologów: dzieła, które wytyczają granice narodu (na podstawie etnicznej lub językowej, historycznej, wyznaniowej - różnie to, jak wiadomo, bywało), a wraz z tym zasięg jego przyszłych aspiracji politycznych, terytorialnych i asymilatorskich (Dyskusja historyków i socjologów, Jerzy Jedlicki: 143).

Tradycyjnie i współcześnie znacząca jest rola inteligencji w ruchu narodowym na Białorusi.

\section{CHARAKTERYSTYKA ZEBRANEGO MATERIALU EMPIRYCZNEGO}

Analizą interpretacyjną objęto 30 wywiadów biograficznych, nagranych w okresie między 1999 a 2008 rokiem, kiedy po kilkuletnim okresie względnej demokratyzacji (w latach 1991-1994), który nastąpił po upadku systemu komunistycznego, na Białorusi zaczął się umacniać system autorytarny. Wśród podstawowych kryteriów doboru osób badanych należy wymienić autodeklarację przynależności do białoruskiej grupy narodowej (za Antoniną Kłoskowską, 1996), odróżniam identyfikację narodową, tożsamą z autodeklaracją przynależności do grupy narodowej, od walencji kulturowej, która, z kolei, określa stopień przyswojenia kultury narodowej) oraz autodeklarację posługiwania się językiem białoruskim we wszystkich lub niektórych sferach życia. Wszyscy narratorzy są obywatelami Białorusi. Wszystkie wywiady nagrano z wykorzystaniem metody badawczej wywiadu narracyjnego autorstwa Fritza Schützego ${ }^{1}$, która pozwala uchwycić proces kształtowania

Więcej na temat opisu metody wywiadu narracyjnego można przeczytać w następujących pracach: Chanfrault-Duchet (1995), Helling (1990), Hermanns (1987), Kaźmierska (1997), Piotrowski (1997), Prawda (1989), Riemann (2006), Rokuszewska-Pawełek (2002), Schuetze (1990) i in. 
się białoruskiej tożsamości narodowej, szczególnie w okresie gwałtownych przemian społecznych i ustrojowych. Ze względu na hermetyczność środowiska, z którego wywodzą się osoby badane, a także z powodu niesprzyjających wszelkim swobodnym badaniom i obserwacjom socjologicznym warunków społeczno-politycznych na Białorusi w objętym badaniem okresie, zastosowano przy doborze narratorów metodę "kuli śniegowej" (z ang. "snowball sampling").

Badana zbiorowość tworzy specyficzną wspólnotę, odrębny świat społeczny (za Anselmem Straussem, 1969). Zastrzec należy, że nie jest to środowisko opozycyjne, które można charakteryzować poprzez analogię do polskiej opozycji demokratycznej okresu PRL. Nie jest to krąg osób zaangażowanych w polityczną walkę. Badana zbiorowość tworzy wspólnotę, którą proponuję nazwać wspólnotą interpretacyjną. Termin ten oznaczałby perspektywę, punkt widzenia, sposób organizowania doświadczeń, który zapanował w pewnym środowisku (tożsamym w dużej mierze ze środowiskiem inteligenckim), tak, że przyjęte przez badane jednostki kategorie myślenia o rzeczywistości, kategorie ważności i nieważności połączyły je we wspólnotę. Badana zbiorowość tworzy środowisko odpowiadające historycznie ugruntowanemu - szczególnie na obszarze dziewiętnastowiecznej Rosji i terenów Polski - zjawisku inteligenckich kółek (Berlin 2003).

Poniżej omawiam „wzorcowy” przypadek (patrz Kaźmierska 2008: 337) wywiadu z białoruskim inteligentem $w$ drugim pokoleniu, przedstawiając go w całości w sposób szczegółowy, ponieważ ukazuje on podstawowe procesy biograficzne i społeczne w kontekście kształtowania się tożsamości narodowej. Poniższy opis odsłania również zakotwiczenie pojedynczych biografii w procesach społecznych zachodzących w okresie życia rodziców narratora i jego samego. Lawon deklaruje białoruską tożsamość oraz użycie języka białoruskiego we wszystkich sferach życia (m.in. w domu i pracy). Pochodzący z etnicznie mieszanej rodziny narrator dokonuje świadomego wyboru tożsamości białoruskiej. Odkrywaniu przynależności do białoruskiego uniwersum symbolicznego towarzyszy refleksja nad wyborem języka białoruskiego jako narzędzia komunikacji w kraju, w którym język ten jest używany przez mniejszość mieszkańców miast. Wybierając język białoruski, wybrał swoją wspólnotę komunikacyjną.

Środowisko rodzinne było dla urodzonego w Mińsku w 1956 roku Lawona źródłem białoruskiej samoidentyfikacji i znajomości języka ojczystego: „znacznie wcześniej niż doszedłem do uświadomienia sobie znaczenia języka białoruskiego czy znaczenia historii czy jeszcze czegoś/ po prostu żyłem w pewnym środowisku/"2. Rodzice narratora byli zawodowymi dziennikarzami: matka pracowała w białoruskiej telewizji, ojciec - w białoruskiej gazecie. W środowisku pracy rodziców panowała dwujęzyczność, z tym że znajomość języka białoruskiego była koniecznością. Przechodzenie z języka rosyjskiego na białoruski i odwrotnie było dla Lawona od dziecka czymś zupełnie naturalnym: „potem nie było żadnych problemów/ tak i obecnie z przejściem z jednego języka na drugil w tym

2 W transkrypcji wywiadów zastosowano uproszczoną wersję systemu zapisu opracowanego przez Gaila Jeffersona (1989):

nie wypowiedź z naciskiem

cóżl intonacja wznosząca (jak w pytaniu)

cóż\ intonacja opadająca (jak w wygłosie na końcu zdania twierdzącego). 
środowisku językowym ponieważ wszyscy poważnie traktowali język białoruskil nawet ci mówiący po rosyjsku".

Rodzice Lawona prezentowali postawę niekonformistyczną wobec ustroju komunistycznego. Ojciec narratora nigdy nie wstąpił do partii komunistycznej. Wszyscy się dziwili: "jak możesz być redaktorem działu [czasopisma] nie będąc członkiem partii/". Dwupokojowe mieszkanie rodziców Lawona, zawsze pełne gości, było popularnym miejscem spotkań znajomych ze studiów i redakcji, literatów, przedstawicieli świata kina, filozofów, jednym słowem, "ciekawych osobistości”. W dużej mierze spotkania te kształtowały światopogląd młodego człowieka: „oczywiście to także miało na mnie wpływ w tym sensie że ci ludzie często nas odwiedzali". W czasie tych spotkań prowadzono "dosyć szczere/ zbyt szczere rozmowy głównie polityczne". Szczerość rozmów odcisnęła piętno na karierze zawodowej rodziców Lawona, ponieważ wśród stałych bywalców "znalazł się kapuś, który doniósł na nich do KGB/ nie tylko doniósł nagrywał na taśmę". W wyniku donosu ojciec narratora stracił pracę, był przesłuchiwany przez KGB i cudem uniknął więzienia. Matce narratora zaproponowano, by sama złożyła wymówienie i tym samym uniknęła przesłuchań oraz innych przykrych konsekwencji. Po jakimś czasie matce udało się znaleźć pracę w państwowej placówce naukowej. Ojciec przez wiele lat był zmuszony pracować w domu, zarabiając głównie jako tłumacz oraz autor artykułów publicystycznych.

Kilkakrotnie w wywiadzie narrator podkreśla rolę rodziców w procesie kształtowania się jego białoruskiej tożsamości narodowej. Świadczy o tym chociażby poniższy incydent, który stał się „punktem zwrotnym” (za Anselmem Straussem, 1969) w biografii Lawona. Mianowicie, w wieku osiemnastu lat Lawon otrzymał lekcję życia od rodziców przy okazji deklarowania swojej narodowości w biurze paszportowym (każdy obywatel radziecki miał wpisaną do dowodu narodowość). Otrzymując dowód, Lawon dokonał najbardziej oczywistego wówczas wyboru: podał narodowość rosyjską (po ojcu). Na wieść o tym po powrocie do domu rodzice urządzili Lawonowi karczemną awanturę: „powiedzieli jak mogłeś/ wyparłeś się matczynej mowy/ jak mogłeś powiedzieć że nie jesteś Białorusinem". W trakcie awantury rodzice po raz pierwszy wprowadzili syna $w$ tajniki pochodzenia etnicznego jego ojca i dziadków ze strony ojca. Wyjaśnili, że babcia Lawona ze strony ojca była na wpół Polką na wpół Rosjanką, dziadek natomiast był Żydem, zapisanym w dokumentach jako Rosjanin, żeby uniknąć problemów w czasie wojny. Matka Lawona jest z pochodzenia Białorusinką. Pod presją rodziców narrator wrócit do biura paszportowego, aby zmienić zapis: "i tak mnie zawstydzili że wrócitem tam i zebrałem całą swoją odwage tak mi się strasznie nie chciało nienawidzę mieć do czynienia z tymi gryzipiórkami ale poszedłem tam i powiedziałem że tak naprawdę jestem Białorusinem\ i zapisali że jestem Białorusinem\".

Opisany incydent stał się dla narratora impulsem do rozważań na temat własnej tożsamości: „zmusiło mnie to do zastanowienia kim i czym jestem\”. Po tym wydarzeniu Lawon nadal na co dzień rozmawiał po rosyjsku, nie widząc $w$ tym niczego zdrożnego: "co z tego wszyscy mówili po rosyjsku〉". Studiował wówczas biologię, ale dojrzewał do decyzji, by, podobnie jak rodzice, zostać dziennikarzem (mimo kategorycznego sprzeciwu ze strony obojga). Studia, a wcześniej szkoła, były rosyjskojęzyczne. Ostatecznie przerwał studia na wydziale biologii i dostał się na dziennikarstwo wieczorowe. Na wydziale dziennikarstwa wielkie wrażenie na narratorze wywarł wykładowca języka białoruskiego Mikoła Ryhorawicz Kawalenka, który miał "dar od Boga" i zaszczepił miłość do języka ojczystego. $\mathrm{Na}$ tej samej uczelni narrator poznał kolejną znaczącą osobę z punktu widzenia swojej 
tożsamości narodowej, również studenta dziennikarstwa, Mikitę Nowaka: „jestem przekonany że podstawową rolę odegrali rodzice a kolejną właśnie Mikita Nowak/". Mikita, który pozostał przyjacielem narratora na całe życie, „zaczął tłumaczyć że jesteśmy Białorusinami zaczął przynosić publikacje/ wydania które zresztą wychodziły jeszcze przed wojną na Litwie/ w języku białoruskim różne takie ciekawe rzeczy/". W ocenie narratora, Mikoła był osobą charyzmatyczną i gdy zaczął rozmawiać po białorusku, wielu, w tym Lawonowi, to imponowato.

Wspólnie z przyjaciółmi narrator zaczął rozmawiać po białorusku, głównie "z chęci zamanifestowania opozycyjności/ niezadowolenia wobec istniejącego rządu czy ładu/". Wspólnie ze swoją grupą odniesienia narrator z wielką przyjemnością wyrażał swoją białoruskość, na przykład rozmawiając w swoim ojczystym języku w miejscach publicznych: „nagle się okazało że można być opozycjonistą po prostu rozmawiając po białorusku i korzystaliśmy z tego i tak z uczuciem rozmawialiśmy w komunikacji miejskiej/". Narrator konstatuje, że ostentacyjne mówienie po białorusku było swoistą modą wśród "świadomej" białoruskiej młodzieży (w latach siedemdziesiątych).

Istniały też bardziej zorganizowane formy zaznaczania swojej białoruskości, jak na przykład kółka i stowarzyszenia o charakterze narodowościowym. Wspólnie z innymi "świadomymi" Białorusinami Lawon uczęszczał na próby chóru ludowego (choć "strasznie nie lubiłem śpiewu/ nie miałem ani słuchu, ani głosu/"). W czasie tych spotkań poznał wielu znanych obecnie opozycyjnych działaczy białoruskich, na przykład późniejszych liderów partii BNF (Białoruskiego Frontu Ludowego), Wincuka Wiaczorkę i Wiktara Iwaszkiewicza. Wspomniane spotkania chóru ludowego przekształciły się w 1986 roku w znany na Białorusi ruch młodzieżowy "Tałaka". Poznani w tym środowisku działacze rozpowszechniali literature drugiego obiegu, "zajmowali się taką pracą u podstaw/ takie broszury”. Dzięki liderom białoruskiego środowiska młodzieżowego, takim jak Wincuk Wiaczorka i "jemu podobnym (...) dowiedziałem się co to biało-czerwono-biała flaga (.) co to Pahonia/ takie podstawowe rzeczy".

Zawarte przyjaźnie przetrwały do końca życia, a narrator został cenionym na Białorusi niezależnym dziennikarzem i pisarzem. Podsumowując wątek odkrywania i krystalizacji swojej tożsamości narodowej, Lawon konstatuje, że poza samokształceniem, także czynniki środowiskowe odegrały w tym procesie dużą rolę: „takie proste rzeczy mianowicie rodzice/ nauczyli że jesteś Białorusinem a nie Rosjaninem\ wykładowca który zaszczepił miłość do języka białoruskiego/ i wreszcie przyjaciele\ (...) a następnie dochodzi do bardziej głębokiego uświadomienia sobie jak bardzo cierpiał ten naród i rozkułaczenie i wojna/ i te wszystkie koszmary po wojniel".

UWAGI KOŃCOWE

Lawon jest typowym przedstawicielem inteligencji, jeśli przyjąć za Chałasińskim, że

Z punktu widzenia socjologicznego inteligent jako typ społeczny wiąże się nieodłącznie z pewnego rodzaju środowiskiem społecznym, z pewną formą życia zbiorowego w ramach określonego ustroju społeczno-kulturalnego, ukształtowanego historycznie (Chałasiński 1997: 48).

Za tym samym autorem można pokusić się o stwierdzenie, że narrator wychował się W "getcie inteligenckim" utworzonym przez rodziców i jako człowiek dorosły wszedł W skład "getta inteligenckiego" swoich rówieśników. Przyswajał sobie tożsamość biało- 
ruską (mimo mieszanego pochodzenia etnicznego) i postawę niekonformistyczną w drodze socjalizacji pierwotnej. Poczucie tożsamości Lawona nie bazuje na pochodzeniu etnicznym, lecz na poczuciu patriotyzmu wobec kraju, w którym mieszka. Mimo że rodzice otwarcie nie narzucali swojego światopoglądu, zareagowali w sposób bardzo emocjonalny, gdy syn zadeklarował narodowość rosyjską w urzędzie paszportowym. Tym samym incydent ten stał się punktem zwrotnym w biografii Lawona.

Inne przykłady punktów zwrotnych w zebranych biografiach zawiera narracja Oli (wywiad 17), która (w latach dziewięćdziesiątych) jako nastolatka wzięła udział w Festiwalu Prasy Młodzieżowej pod Mińskiem. W czasie festiwalu narratorka poznała Ukraińców ze Lwowa, rozmawiających między sobą po ukraińsku, którzy byli zszokowani, że w stolicy Białorusi na palcach jednej ręki można policzyć osoby mówiące po białorusku. Zaskoczenie grupy ukraińskiej było tak silne i na tyle mocno wpłynęło na narratorkę, że Ola postanowiła odtąd rozmawiać ze wszystkimi po białorusku i dotrzymała słowa. Z kolei Jurek (wywiad 21) przeżył swoją „konwersję” 30 października 1988 roku, w dniu obchodzenia święta Dziady w Mińsku, kiedy doszło do krwawego stłumienia pokojowej manifestacji. Narrator powiedział do siebie: "koniec Jurkul poczynając od dnia dzisiejszegol rozmawiasz wyłącznie po białoruskul bez względu na okolicznościl zawsze i wszędzie/" i od tamtej pory po dziś dzień Jurek rozmawia wyłącznie po białorusku. Zebrane wywiady odsłaniają też głębszy proces odkrywania przez narratorów w życiu dorosłym doniosłości języka ojczystego jako wyznacznika przynależności narodowej. Proces uświadamiania sobie roli języka białoruskiego w życiu jednostki, jak również zbiorowości etnicznej oraz proces świadomego uczenia się języka (często od podstaw) stanowi jeden z etapów krystalizacji tożsamości narodowej współczesnych Białorusinów. W ślad za językiem podąża uczestnictwo w symbolicznej kulturze białoruskiej i sięganie do zasobów historii oraz pamięci zbiorowej, co ostatecznie prowadzi do świadomej identyfikacji z ojczyzną w sensie symbolicznym, szerszym niż czysto terytorialne odniesienie.

Narracja Lawona podkreśla role „znaczących innych” i grup odniesienia w kształtowaniu się białoruskiej tożsamości narodowej, która polegała między innymi na wzbogacaniu wiedzy z zakresu narodowej symboliki, kultury i historii, „alternatywnej” względem symboliki, kultury i historiografii radzieckiej. Na Białorusi istnieje więcej niż jedna zbiorowość o charakterze kulturowym w obrębie jednego państwa. Przypomina to sytuację Polski z okresu PRL, kiedy wspótistniały oficjalny i „drugi” obieg kultury. Adresaci wytworów oficjalnego i "drugiego" obiegu kultury należą do różnych uniwersów symbolicznych, mimo zamieszkiwania na terenie tego samego państwa. Sytuacja ta jest typowa dla państw autorytarnych, do których zaliczamy współczesną Białoruś, gdzie nawet wybór języka biatoruskiego lub rosyjskiego jest wyborem o zabarwieniu ideologicznym, który rzutuje między innymi na ścieżkę kariery zawodowej i inne wybory życiowe.

W wywiadach najczęściej powtarzają się następujące nazwiska „znaczących innych” w środowisku inteligencji: Aleh Trusau (historyk), Aleksiej Karpiuk (pisarz), Zianon Paźniak (polityk), Danuta Biczel-Zahnietawa (poetka), Aleś Biełakoz (nauczyciel), Michaś Tkaczou (historyk), Wincuk Wiaczorka (działacz BNF) i inni. Na przykład Paweł (wywiad 18) mówi, że zaczął brać udział w terenowych badaniach archeologicznych pod kierunkiem Tkaczoua, "który pokazał im Białoruś”, był „ojcem chrzestnym setek Białorusinów”. Albo Anton (wywiad 6), któremu na studiach „brakowało jakichś wyższych celów”, wreszcie w 1978 roku "niespodziewanie poznał grupę ludzi mówiących po białorusku, między innymi Aleha Trusaua i Zianona Paźniaka". Życie Andrzeja (wywiad 23) z kolei całkowicie się zmieniło, odkąd zaczął uczęszczać na spotkania w Muzeum im. Maksyma Bohdanowicza w Grod- 
nie, którego dyrektorem była wówczas znakomita poetka Danuta Biczel-Zahnietawa, „której nikt nie może zastąpić".

Białoruskojęzyczni narratorzy z reguły przywołują okres „pieriestrojki” jako ważny okres z punktu widzenia budowania zbiorowej i jednostkowej tożsamości narodowej. Wówczas

Tworzyły się nieformalne inteligenckie grupy dyskusyjne, których uczestnicy chcieli reformować świat komunizmu, nie podważając jego podstawowych wartości. Jedynie kilkunastoosobowe organizacje młodzieżowe - mińska "Tałaka” i grodzieńska „Pahonia” - wzywały do bojkotu radzieckiego porządku prawnego, nie proponując jednak żadnych konstruktywnych rozwiązań. Dopiero powstanie Białoruskiego Frontu Ludowego „Odrodzenie” w końcu 1988 roku zapoczątkowało ruch na rzecz przywrócenia rangi języka białoruskiego i upowszechniania kultury narodowej (Miranowicz 2003: 17).

Narratorzy powołują się także na inne istotne okresy i wydarzenia, takie jak polityka powszechnej białorusizacji Szuszkiewicza w latach 1990-1994 czy referendum z 1995 roku (w następstwie którego wprowadzono dwa języki urzędowe na Białorusi oraz zmieniono symbolikę państwową z białoruskiej na radziecką). Na przykład Wiktor (wywiad 3) zaczął mówić po białorusku w akcie obywatelskiego nieposłuszeństwa wobec wspomnianego referendum

W przypadku zebranych narracji możemy mówić o „hipertrofii tożsamości” („identity spread", Strauss 1969) czyli zogniskowaniu biografii, w tym wypadku, wokół problematyki tożsamości narodowej. Nic dziwnego, skoro proces budowania białoruskiej tożsamości wymaga natężonej pracy biograficznej, ponieważ białoruskojęzyczność najczęściej nie jest wynikiem pierwotnej socjalizacji. Narratorzy wspominają także o dużym wysitku intelektualnym, niektórzy poświęcają życie zawodowe studiowaniu ojczystej historii, języka czy literatury, albo oddają się działalności obywatelskiej czy politycznej. Poszukują odpowiedniego środowiska, z którym mogą dzielić swoje poglądy. Zebrane wywiady odsłaniają także paradygmaty emancypacyjne istniejące w społeczeństwie białoruskim, które plasują się na kontinuum od tradycji romantyczno-nacjonalistycznej po reformatorsko zorientowany prookcydentalizm. Mimo że tendencje te na razie nie są skutecznie skonsumowane przez polityczną opozycję na Białorusi, stanowią istotny potencjał rozwojowy wobec anachronicznej już tożsamości (po)radzieckiej.

\section{LITERATURA}

Anderson, Benedict, 1997, Wspólnoty wyobrażone. Rozważania o źródłach i rozprzestrzenianiu się nacjonalizmu, (przekł. Stefan Amsterdamski), Kraków: Znak.

Berlin, Isaiah, 2003, Rosyjscy myśliciele, Warszawa: Prószyński i Spółka.

Buczyński, Andrzej, 2010, Wybrane aspekty zapadnoruskiej tożsamości, (w:) R. Radzik, M. Sajewicz (red.), 2010, Białoruś - przeszłość i teraźniejszość: kultura, literatura, język, Lublin: Wydawnictwo Uniwersytetu Marii Curie-Skłodowskiej, s. 11-22.

Burszta, Wojciech Józef, 2004, Różnorodność i tożsamość. Antropologia jako kulturowa refleksyjność, Poznań: Wydawnictwo Poznańskie.

Chałasiński Józef, 1997, Przeszłość i przyszłość inteligencji polskiej, Warszawa: Świat Książki.

Chanfrault-Duchet, Marie Francoise, 1995, Biographical Research in Former West Germany, "Current Sociology", vol. 43, No 2/3, s. 209-219. 
Dyskusja historyków i socjologów (Jerzy Jedlicki, Maria Bogucka, Jerzy J. Smolicz, Janusz Tazbir, Juliusz Domański, Andrzej Szpociński, Joanna Kurczewska, Andrzej Tyszka, Maria Falińska, Leszek Korporowicz), 1992, „Kultura i Społeczeństwo”, tom XXXVI, nr 1: 143-156.

Eames, Marion, 1997, A Private Language? A Dip into Welsh Literature, Llandysul, Ceredigion: Gomer Press.

Engelking, Anna, 2001, Guest Editor's Introduction to 'Belarus: Between the East and the West', "International Journal of Sociology", vol. 31, no. 3, s. 3-10.

Gellner, Ernest, 1994, Encounters with Nationalism, Oxford.

Goujon, Alexandra, 1999, Language, Nationalism, and Populism in Belarus, "Nationalities Papers" Vol. 27, No. 4, s. 661-677.

Helling, Ingeborg K., 1990, Metoda badań biograficznych, (w:) Włodarek, J. i M. Ziółkowski (red.), Metoda biograficzna w socjologii, Warszawa-Poznań: PWN, s. 13-37.

Hermanns, Harry, 1987, Narrative Interviews - a New Tool for Sociological Field Research, "Folia Sociologica”, nr 13, Łódź: Wyd. Ut, s. 43-56.

Jefferson, Gail, 1989, An Exercise in the Transcription and Analysis of Laughter, (w:) Van Dijk Teun A. (red.) Handbook of Discourse Analysis, Vol. 3 Discourse and Dialogue, London: Academic Press, s. 25-34.

Kaźmierska, Kaja, 2008, Biografia i pamięć na przykładzie pokoleniowego doświadczenia ocalonych z zagłady, Kraków: Nomos.

—, 1997, Wywiad narracyjny - technika i pojecia analityczne, (w:) Czyżewski M., A. Piotrowski i A. Rokuszewska-Pawełek (red.), Biografia a tożsamość narodowa, Łódź: Ut, s. 35-44.

Kłoskowska, Antonina, 1996, Kultura narodowa u korzeni, Warszawa: PWN.

Kraucewicz, Aleksander, 1999, Białoruś jako podmiot własnej historii. Maszynopis w posiadaniu autorki.

Miranowicz, Eugeniusz, 2003, Najnouszaja Historyja Biełarusi (Najnowsza historia Białorusi), Sankt-Petersburg: Nieuski prastiah.

Piotrowski, Andrzej, 1997, Wstęp, (w:) Czyżewski M., A. Piotrowski i A. RokuszewskaPawełek (red.), Biografia a tożsamość narodowa, Łódź: Ut, s. 5-12.

Prawda, Marek, 1989, Biograficzne odtwarzanie rzeczywistości, "Studia Socjologiczne”, nr 4, s. 81-98.

Radzik, Ryszard, 2002, Kim są Białorusini?, Toruń: Wydawnictwo Adam Marszałek.

Riemann, Gerhard, 2006, An Introduction to "Doing Biographical Research", "Historical Social Research", Vol. 31, No. 3: 6-28.

Rokuszewska-Pawełek, Alicja, 2002, Chaos i przymus. Trajektorie wojenne Polaków analiza biograficzna, Łódź: Wydawnictwo Ut.

Schuetze, Fritz, 1990, Presja i wina: doświadczenia młodego żołnierza niemieckiego w czasie I/ wojny światowej i ich implikacje biograficzne, (w:) Włodarek J., M. Ziółkowski (red.), Metoda biograficzna w socjologii, Warszawa-Poznań: PWN.

Straczuk, Justyna, 1999, Język a tożsamość człowieka, Warszawa: Wydawnictwo Uniwersytetu Warszawskiego.

Strauss, Anselm L., 1969, Mirrors and Masks. The Search for Identity, CA: The Sociology Press.

Tomaszewski Jerzy, 1991, Białorusini w oczach Polaków, 1918-1939, „Literatura na Świecie", sierpień-wrzesień 1991, nr 8-9, s. 221-241. 


\section{Summary}

Drawing on a case study from the body of empirical research which includes 30 narrative interviews conducted using Fritz Schuetze's biographical method with male and female residents of Belarus, the author explores the process of Belarusian identity formation of a Belarusian-speaking dissenting intellectual. The case study is drawn from the author's research into the ways in which Belarusianspeaking intellectuals (the group locating itself in opposition to the establishment by the very recourse to the literary Belarusian language of instruction and everyday life as well as other dissenting identity markers) conceptualize and hone their national identity. One can trace the path towards fullyfledged Belarusian identity which unrolls via turning points, thanks to significant others through participation in intelligentsia circles. One of the membership rules in the social world of intelligentsia is the use of the high-profile Belarusian language. The interpretive analysis is set against the backdrop of the socio-linguistic situation in contemporary Belarus with its authoritarian regime, advanced Russification, contested memory field, restrained memory work and conflicting historical and national discourses.

Key words: intelligentsia, biographies, national identity, Belarus 